\title{
Isolation and Identification of Antifungal Substances from "Akagusare"-infected Laver Porphyra sp.
}

\author{
Hiroyuki Noda, ${ }^{* 1}$ Hideomi Amano, ${ }^{* 1}$ Satoshi Kano, ${ }^{* 2}$ and Fusao OHTA ${ }^{* 3}$ \\ (Accepted January 21, 1983)
}

\begin{abstract}
The antifungal substances effective against "akagusare"-infected Porphyra sp. were isolated by gas liquid chromatography equipped with a preparative apparatus. After being methylated, those substances were analyzed by gas chromatography-mass spectrometry. The data obtained, together with their infrared spectra, indicated that they are phenylacetic acid, unsaturated fatty acids such as octenoic, nonenoic, and nonedienoic acids, and saturated fatty acids such as nonanoic and heptanoic acids. The antifungal substances in $\mathrm{F}-1$ one of the organic acid fractions, showed much higher levels in the infected and the recovered laver than in the normal laver.
\end{abstract}

As reported in the preceding paper," "akagusare"-infected laver Porphyra sp. gave rise to some unsaturated fatty acids as antifungal substances when a small amount of histidine was added, resulting in the recovery of the disease. This paper deals with the isolation and identification of those antifungal substances.

\section{Materials and Methods}

\section{Materials}

The normal, "akagusare"-infected, and histidine-treated recovering specimens of laver Porphyra sp. used were the same as in the preceding paper. ${ }^{1)}$

\section{Bioassay}

The percentage inhibition of the growth of Pytium porphyrae was measured as reported in the preceding paper. ${ }^{1)}$

\section{Isolation Method of Antifungal Substances}

The organic acid fractions (Fig-1 F-6) containing most of the antifungal activity was obtained from the laver by the method reported in the preceding paper. ${ }^{1)}$ The organic acids contained were converted to methylesters by treating with diazomethane. ${ }^{2)}$ The methylated substances were evaporated to dryness under reduced pressure at $35^{\circ} \mathrm{C}$, and dissolved in a small amount of $n$-hexane.
Two $\mu l$ of the solution thus provided was injected into a Yanagimoto model G-1800 gas liquid chromatograph equipped with a flame ionization detector. A glass column $(3.0 \mathrm{~mm}$ i.d. $\times 2 \mathrm{~m})$ packed with $5 \%$ Sinchrome E 71 on $60 \sim 80$ mesh Shimalite $\mathrm{AW}$ was used. The temperature was programmed from 50 to $150^{\circ} \mathrm{C}$ at a rate of $4^{\circ} \mathrm{C} / \mathrm{min}$. Nitrogen was used as carrier gas at $49 \mathrm{~m} / / \mathrm{min}$. Any component in the major peaks was recovered by the capillary tube technique.

\section{Spectral Analyses}

IR in chloroform and carbontetrachloride were recorded with an IR A-1 spectrometer of Japan Spectroscopic Co., LTD. Combined gas chromatography-mass spectrometry (GC-MS) for analyses of fatty acid methylesters was performed with a GC-MS Hitachi M-80 spectrometer. A glass column ( $30 \mathrm{~m}$ scot goray column packed with Thermon $600 \mathrm{~T}$ ) was operated at 70 to $230^{\circ} \mathrm{C}$ with a temperature raise at $5^{\circ} \mathrm{C} / \mathrm{min}$.

\section{Results and Discussion}

\section{$G L C$}

Organic acid fractions, F-1 (100 mg), F-2 (11 $\mathrm{mg}$ ) and F-3 (28 mg) showing a high antifungal action were obtained from $19.1 \mathrm{~kg}$ of the infected specimen of laver. It follows that the antifungal substances are contained at a level of $139 \mathrm{mg} /$

*1 Laboratory of Marine Biochemistry, Fuculty of Fisheries, Mie University, Tsu, Mie 514, Japan (野田宏 行・天野秀臣: 三重大学水痖学部).

*2 Laboratory of Marine Biochemistry, Faculty of Agriculture, The University of Tokyo, Bunkyo, Tokyo 113, Japan (加納 哲: 東京大学费学部).

*3 Formerly, Kumamoto Prefectural Laver Research Laboratory, Misumi, Udo, Kumamoto 869-32, Japan (太田扶桑雄：前熊本紧のり研究所)。 


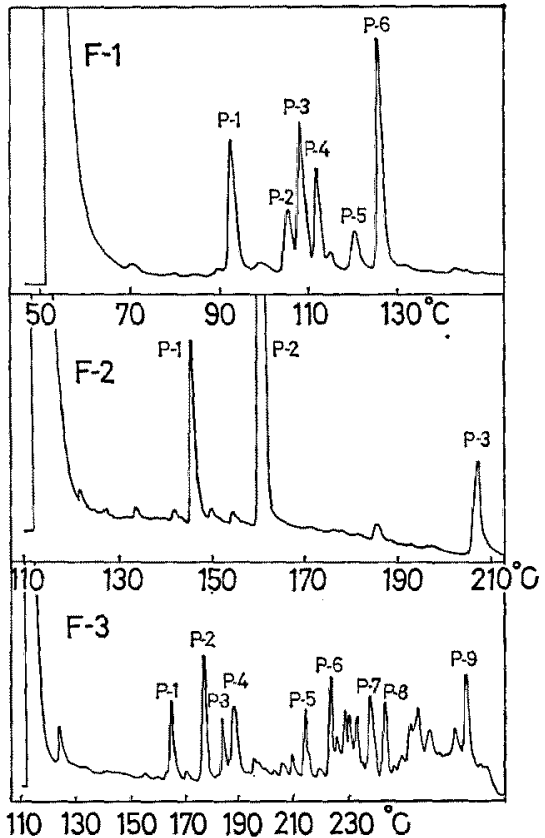

Fig. 1. Gas chromatograms of F-1, F-2 and F-3 after methylation.

Table 1. Yields of fatty acids from the infected laver $(19.1 \mathrm{~kg})$

\begin{tabular}{|c|c|}
\hline Fraction No. & Peak No. \\
\hline $\mathrm{F}-1(100 \mathrm{mg})$ & $\begin{array}{l}\text { P-1 }(2.25 \mathrm{mg}) \\
\text { P-2 }(0.45 \mathrm{mg}) \\
\text { P-3 }(1.53 \mathrm{mg}) \\
\text { P-4 }(0.45 \mathrm{mg}) \\
\text { P-5 }(2.56 \mathrm{mg}) \\
\text { P-6 }(2.45 \mathrm{mg})\end{array}$ \\
\hline $\mathrm{F}-2(11 \mathrm{mg})$ & $\begin{array}{l}\text { P-1 }(0.46 \mathrm{mg}) \\
\text { P-2 }(1.00 \mathrm{mg}) \\
\text { P-3 }(0.05 \mathrm{mg})\end{array}$ \\
\hline$F-3(28 \mathrm{mg})$ & $\begin{array}{l}\text { P-1 }(0.09 \mathrm{mg}) \\
\text { P-2 }(0.01 \mathrm{mg}) \\
\text { P-3 }(0.08 \mathrm{mg}) \\
\text { P-4 }(0.05 \mathrm{mg}) \\
\text { P-5 }(0.16 \mathrm{mg}) \\
\text { P-6 }(0.03 \mathrm{mg}) \\
\text { P-7 }(0.02 \mathrm{mg}) \\
\text { P-8 }(0.02 \mathrm{mg}) \\
\text { P-9 }(0.05 \mathrm{mg})\end{array}$ \\
\hline
\end{tabular}

$19.1 \mathrm{~kg}$ on wet basis, or approximately at $70 \mathrm{ppm}$ on dry basis. Each of these fractions usually contained several active components, and hence

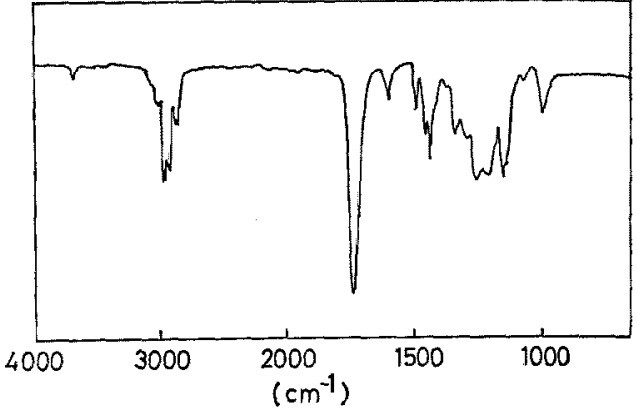

Fig. 2. Infrared spectrum of P-1 from F-1.

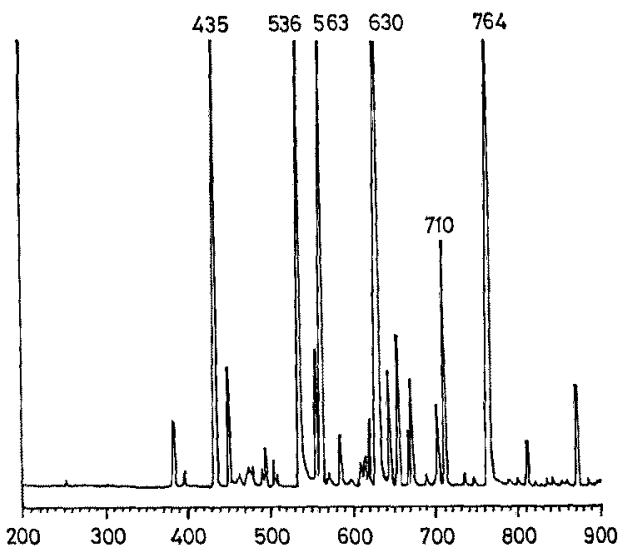

Fig. 3. Gas chromatography-mass spectrometry of F-1 after methylation.

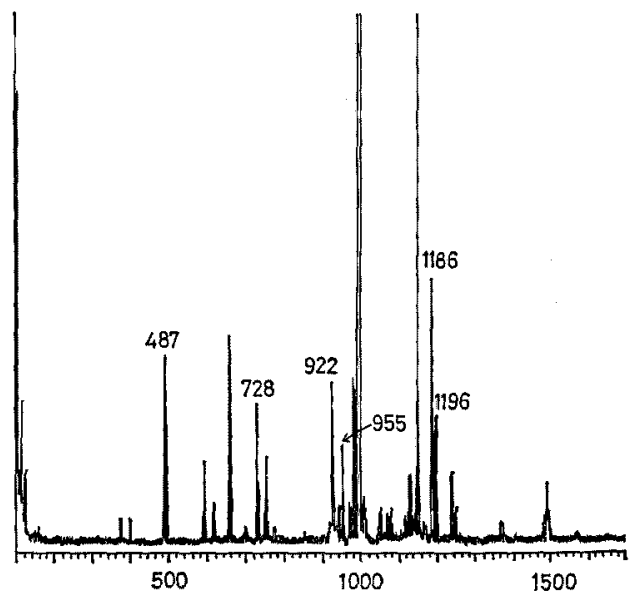

Fig. 4. Gas chromatogram of organic acid methylesters from a mixture of F-2 and F-3. 


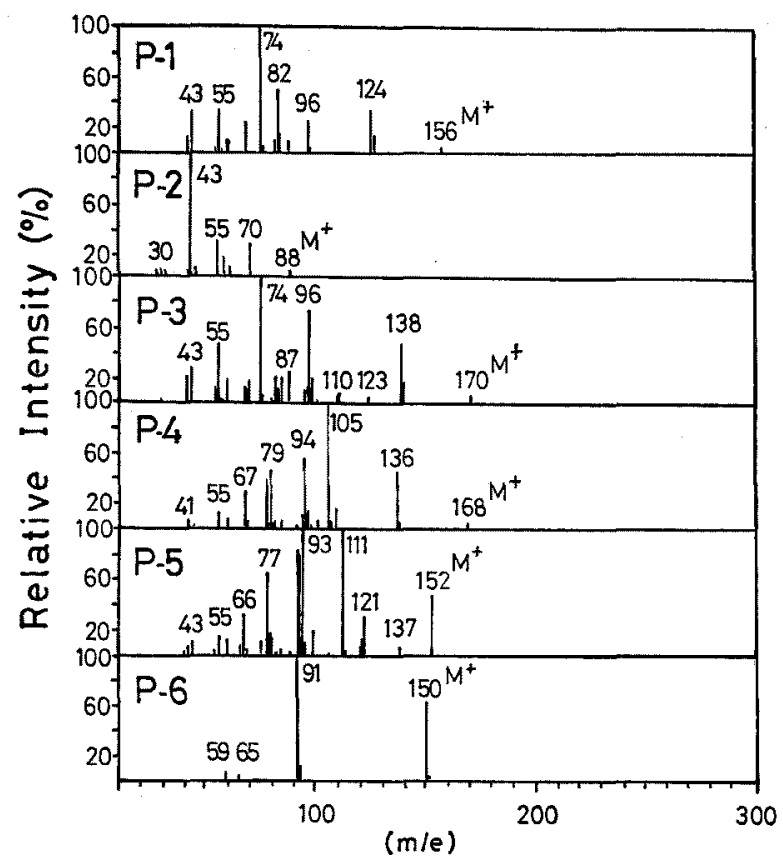

Fig. 5. Mass spectra of organic acid methylesters $(P-1 \sim 6)$ isolated from the infected laver.

Table 2. Identification of the antifungal substances isolated from the infected and recovered lavers

\begin{tabular}{|c|c|c|c|c|}
\hline Fraction & $\begin{array}{l}\text { Scan } \\
\text { No. }\end{array}$ & $\mathbf{M}^{+}$ & Identified as: & Rational formula \\
\hline \multirow{4}{*}{ F-1 } & 435 & 156 & Octenoic acid & $\mathrm{CH}_{8}\left(\mathrm{CH}_{2}\right)_{4} \mathrm{CH}: \mathrm{CH} \mathrm{COOH}$ \\
\hline & 563 & 170 & Nonenoic acid & $\mathrm{CH}_{3}\left(\mathrm{CH}_{2}\right)_{4} \mathrm{CH}: \mathrm{CH} \mathrm{CH} \mathrm{CHOH}_{2} \mathrm{COOH}$ \\
\hline & 630 & 168 & Nonadienoic acid & $\mathrm{CH}_{8} \mathrm{CH}_{2} \mathrm{CH}: \mathrm{CH} \mathrm{CH} \mathrm{CH}_{2} \mathrm{CH} \mathrm{CH} \mathrm{CH}_{2} \mathrm{COOH}$ \\
\hline & 764 & 150 & Phenylacetic acid & $\mathrm{C}_{8} \mathrm{H}_{4} \mathrm{CH}_{2} \mathrm{COOH}$ \\
\hline \multirow{6}{*}{$F-2, F-3$} & 487 & 98 & 4-Methyl-valeric acid & $\mathrm{CH}_{3} \mathrm{CH}\left(\mathrm{CH}_{2}\right) \mathrm{COOH}$ \\
\hline & 728 & 172 & Nonanoic acid & $\mathrm{CH}_{3}\left(\mathrm{CH}_{2}\right)_{7} \mathrm{COOH}$ \\
\hline & 922 & 144 & Heptanoic acid & $\mathrm{CH}_{3}\left(\mathrm{CH}_{2}\right)_{5} \mathrm{COOH}$ \\
\hline & 955 & 182 & Decadienoic acid & $\mathrm{CH}_{3}\left(\mathrm{CH}_{2}\right)_{2} \mathrm{CH}: \mathrm{CH} \mathrm{CH} \mathrm{CH}_{2} \mathrm{CH}: \mathrm{CH} \mathrm{CH}_{2} \mathrm{COOH}$ \\
\hline & 1186 & 236 & Tetradecatrienoic acid & $\mathrm{CH}_{3}\left(\mathrm{CH}_{2}\right)_{2} \mathrm{CH}: \mathrm{CH} \mathrm{CH} \mathrm{CH}_{2} \mathrm{CH}: \mathrm{CH} \mathrm{CH}: \mathrm{CH}\left(\mathrm{CH}_{2}\right)_{8} \mathrm{COOH}$ \\
\hline & 1196 & 223 & Tridecatrienoic acid & $\mathrm{CH}_{8}\left(\mathrm{CH}_{2}\right)_{2} \mathrm{CH}: \mathrm{CH} \mathrm{CH}: \mathrm{CH} \mathrm{CH} \mathrm{CH}_{2} \mathrm{CH}\left(\mathrm{CH}_{2}\right)_{2} \mathrm{COOH}$ \\
\hline
\end{tabular}

was further purified by preparative gas chromatography on $5 \%$ Sinchrome E 71 . F-1 was separated into six major peaks (P-1 P-6), F-2 into three major peaks (P-1 P-3), and F-3 into nine peaks (P-1 P-9) (Fig. 1). Each of these peaks were collected in a capillary tube by the preparative apparatus. Many of the components thus collected showed a remarkable antifungal action. The yields of respective peak components are shown in Table 1.

Antifungal substances are supposed to be localized around damaged cells.
IR Spectra

IR absorption spectra of those peak components were similar to each other. The data of P-6 from F-1 are shown in Fig. 2, for example. Welldefined bands at 3000,1600 and $990 \mathrm{~cm}^{-1}$, indicate the presence of double bonds, those at 2960 and $1400 \mathrm{~cm}^{-1}$ of methylesters, that at $1440 \mathrm{~cm}^{-1}$ of $\mathrm{COOCH}_{3}$, and those at 1710 and $1270 \mathrm{~cm}^{-1}$ of $\mathrm{COOH}$.

\section{$G C-M S$}

The gas chromatograms of organic acid methyl- 


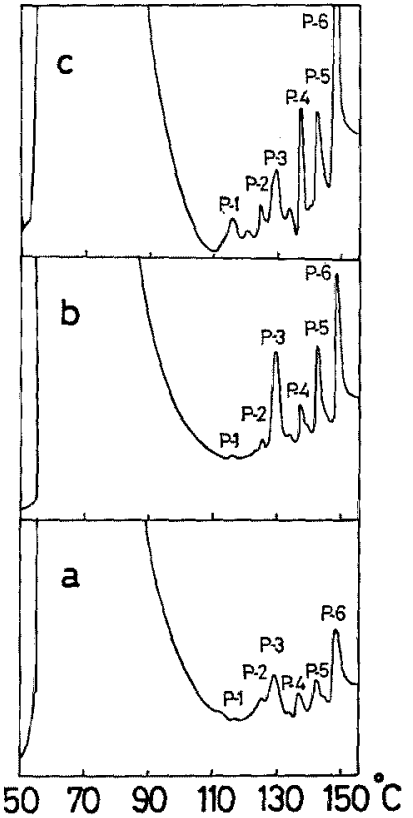

Fig. 6. Gas chromatograms of fatty acid methylesters isolated from the recovered (a), infected (b), and normal laver (c).

esters from $F-1$, and F-2 plus $F-3$ are shown in Figs. 3 and 4, respectively. As shown in Fig. 3, scan No. 435, 536, 563, 630, 710 and 764 correspond to $P-1,2,3,4,5$ and 6 of $F-1$, respectively. In Fig. 4, scan No. 487, 728, 922, 955, 1186 and 1196 correspond to P-1, 3, 4, 6, 7 and 8 of F-3, reapectively. The six peaks of $F-1$ were subjected to mass spectrometry (Fig. 5). The structures of these antifungal substances were determined exactly according to the table of Gysel, ${ }^{3)}$ by reference to the $\mathrm{m} / \mathrm{e}$ data of molecular ions and intensity ratios of the fragment ions (Table 2). These antifungal substances were identified by $\mathrm{GC}$ MS as follows. The unsaturated fatty acids were octenoic, nonenoic, nonadienoic, decadienoic, tetradecatrienoic and tridecatrienoic acids.
Phenylacetic acid and the saturated fatty acids such as valeric, nonanoic and heptanoic acids were also identified.

Changes in the Concentration of Antifungal Substances

As shown in Fig. 6, inhibitory substances, which were present only in a small amount in uninfected fronds, increased with progress of "akagusare" disease of laver. In the recovering histidine-treated fronds, the levels of antifungal components increased further compared with those of the normal frond. Phenylacetic acid was the most active substance, as far as the present data are concerned.

It was found here that some fatty acids and phenylacetic acid may play an important role in the resistance of laver against the disease. These fatty acids may penetrate into the laver, recovering the disease. The amounts of these acids were increased when the infected lavers were treated with a seawater to which histidine was added at $10 \mathrm{ppm}$ previously. These antifungal acids, which accumulated as a dynamic response to the fungal penetration and protected the fronds from infection and subsequent decay by $P$. porphyrae, could be nothing else than phytoalexins.

\section{Acknowledgement}

The present work was partly supported by a research fund granted from the Ministry of Education, Science and Culture.

\section{References}

1) H. Noda, H. Amano, S. Kano, and F. Ohta: Bull. Japan. Soc. Sci. Fish., 49, 1583-1586 (1983).

2) T. Obata, T. Suzuki, and H. Iwao: in "Handbook of Food Analysis", Kenpakusha, Tokyo, 1977, pp. 184-185.

3) H. Grsel: in "Prozent Tabellen der Organischen Verbindungen vom Typus", Birkhauser Verlag, Basel und Stuttgart, Germany, 1951, pp. 9-118. 